O. MAREK SAJ CSSR

Wydział Prawa Kanonicznego

Uniwersytetu Kardynała Stefana Wyszyńskiego w Warszawie

ORCID: 0000-0002-0365-1277

\title{
SPOSOBY PRZECIWDZIAŁANIA POWSTANIU ZGORSZENIA W ŚWIETLE KODEKSU PRAWA KANONICZNEGO Z 1983 ROKU
}

Treść: Wstęp. - 1. Relacje duchownych mogące wywołać zgorszenie. - 2. Wykluczenie zgorszenia przy sprawowaniu Eucharystii w świątyni niekatolickiej. - 3. Wykluczenie zgorszenia przy spowiedzi z udziałem tłumacza. - 4. Zgorszenie a zachowanie tajemnicy o tajnym zawarciu małżeństwa. - 5. Niebezpieczeństwo zgorszenia z powodu pogrzebu jawnych grzeszników. - 6. Zachowanie sekretu w procesie karnym i spornym. - 7. Zapobieżenie zgorszeniu przy przesłuchiwaniu świadków. - 8. Zapobiegawcze zarządzenia ordynariusza. - Zakończenie.

\section{Wstęp}

Zgorszenie - zgodnie z definicją zawartą w Katechizmie Kościoła katolickiego - „jest postawą lub zachowaniem, które prowadzi drugiego człowieka do popełnienia zła. Ten, kto dopuszcza się zgorszenia, staje się kusicielem swego bliźniego. Narusza cnotę i prawość; może doprowadzić swego brata do śmierci duchowej. Zgorszenie jest poważnym wykroczeniem, jeśli uczynkiem lub zaniedbaniem dobrowolnie doprowadza drugiego człowieka do poważnego wykroczenia"1. O wadze takich zachowań mogą świadczyć także słowa Jezusa zapisane w Ewangelii św. Łukasza, gdzie czytamy: „Rzekł znowu do swoich

\footnotetext{
${ }^{1}$ Katechizm Kościoła katolickiego, 11 października 1992, Poznań 1994, nr 2284.
} 
uczniów: Niepodobna, żeby nie przyszły zgorszenia; lecz biada temu, przez którego przychodzą. Byłoby lepiej dla niego, gdyby kamień młyński zawieszono mu u szyi i wrzucono go w morze, niż żeby miał być powodem grzechu jednego z tych małych. Uważajcie na siebie!”2. Podobnie wypowiada się św. Paweł: „Baczcie jednak, aby to, iż wiecie [jak należy postępować], nie stało się dla słabych powodem do zgorszenia”3. „Przestańmy więc wyrokować jedni o drugich. A raczej tak osądźcie, by nie dawać bratu sposobności do upadku lub zgorszenia"4.

Choć zagadnienie zgorszenia bardziej właściwe jest teologii moralnej, nie jest również obce prawu kanonicznemu. Pojęcie to w obecnie obowiązującym Kodeksie prawa kanonicznego występuje 28 razy $^{5}$ w kontekście różnych prawnych instytucji. W niniejszym opracowaniu uwaga zastanie zwrócona na te sytuacje, które potencjalnie moga wywołać zgorszenie wśród wiernych - jeszcze do niego nie doszło, ale możliwe jest jego wystąpienie. Mając to na uwadze, prawodawca kodeksowy poleca podjęcie odpowiednich działań. By można było je lepiej zrozumieć, poszczególne kwestie zostaną, na ile to konieczne, poszerzone o zobrazowanie danej normy. W tak wyznaczonych ramach badawczych przeanalizowanych zostanie osiem kanonów ${ }^{6}$, które dotyczą przeciwdziałania powstaniu zgorszenia.

\section{Relacje duchownych mogące wywołać zgorszenie}

„Duchowni powinni odnosić się z należytą roztropnością do osób, do których uczęszczanie mogłoby narazić na niebezpieczeństwo ich obowiązek zachowania wstrzemięźliwości lub wywołać zgorszenie

${ }^{2}$ Łk 17, 1-2.

${ }^{3} 1$ Kor 8,9 .

${ }^{4} \mathrm{Rz} 14,13$.

${ }^{5}$ Zob. Codex Iuris Canonici auctoritate Ioannis Pauli PP. II promulgatus. Kodeks Prawa Kanonicznego. Przekład polski zatwierdzony przez Konferencję Episkopatu, Poznań 1984 (dalej: KPK), kan. $277 \$ 2,326 \$ 1,695 \$ 1,696 \$ 1,703,933,990,1132$, $1184 \S 1 \mathrm{nr} 3,1211,1318,1328 \S 2,1339 \$ 2,1341,1344 \mathrm{nr} 2-3,1347 \S 2,1352 \S 2,1357$ $\S 2,1361 \S 3,1364 \S 2,1394 \$ 1,1395 \$ 1,1399,1455 \S 3,1560 \S 2,1722,1727 \S 2$.

${ }^{6}$ Tamże, kan. $277 \S 2,933,990,1132,1184 \$ 1,1455,1560 \S 2,1722$. 
wiernych"7 - czytamy w Kodeksie prawa kanonicznego z 1983 roku. Norma ta jest ściśle powiązana z paragrafem pierwszym cytowanego kanonu ${ }^{8}$. Prawodawca przypomina w nim zobowiązanie do zachowania celibatu, podając przy okazji znaczenie tego prawnego wymogu. Nie jest on ograniczony tylko i wyłącznie do życia bezżennego, co ma swój skutek także w przeszkodzie do zawarcia małżeństwa („Nieważnie usiłują zawrzeć małżeństwo ci, którzy otrzymali święcenia”), ale dotyczy wszystkich zachowań, które byłyby przeciwne temu zobowiązaniu. Chodzi zatem tutaj, według Michała Grochowiny, o całkowitą wstrzemięźliwość seksualną duchownych ${ }^{10}$.

Prawodawca przewiduje, że niektóre zachowania mogą być niebezpieczne, jeśli chodzi o zachowanie wstrzemięźliwości, a nawet wywoływać zgorszenie wiernych. Zapis taki stoi na straży życia duchownych w czystości. Powinni oni z należytą roztropnością odnosić się do niektórych osób. Sformułowanie to jest bardzo ogólne i wymaga komentarza. Można bowiem pytać: O jakie zachowania i osoby chodzi? Na kogo winni oni uważać? W jaki sposób? Norma kodeksowa na te pytania nie odpowiada, jak to czynił poprzedni Kodeks. Jego normy mówiły wprost o kontaktach duchownych z kobietami: o uczęszczaniu do nich albo ich przebywaniu u duchownych, co mogłoby być dla nich zagrożeniem lub wywołać zgorszenie ${ }^{11}$. Oobowiązujący Kodeks

${ }^{7}$ Tamże, kan. $277 \$ 2$.

8 Tamże, kan. 277 \$1: „Duchowni obowiązani są zachować ze względu na królestwo niebieskie doskonałą i wieczystą wstrzemięźliwość; i dlatego zobowiązani są do celibatu, który jest szczególnym darem Bożym, dzięki któremu święci szafarze mogą niepodzielnym sercem łatwiej złączyć się z Chrystusem, a także swobodniej oddać się służbie Bogu i ludziom”.

${ }^{9}$ Tamże, kan. 1087.

${ }^{10}$ Por. M. Grochowina, Zobowiązanie duchownych do celibatu wedtug Kodeksu Prawa Kanonicznego z 1983 r., Kościół i Prawo 1 (14) 2012, s. 19.

${ }^{11}$ Codex Iuris Canonici Pii X Pontificis Maximi iussu digestus Benedicti Papae XV auctoritate promulgatus, Typis Polyglottis Vaticanis 1943 (dalej: CIC), can. $133 \$ 1$ : „Caveant clerici ne mulieres, de quibus suscipio esse possit, apud se retineant aut quoquo modo frequentent". 
prawa kanonicznego używa określenia „osoby”, czyli chodzi zarówno o kobiety, jak i o mężczyzn ${ }^{12}$.

Warto w tej materii przywołać kolejny paragraf analizowanego kanonu, który stanowi, że „biskup diecezjalny może wydać bardziej szczegółowe normy w tej sprawie i oceniać w poszczególnych przypadkach zachowanie tego obowiązku"13. Podobnie brzmi norma poprzednio obowiązującego Kodeksu, według którego ordynariusz miejsca miał prawo osądu co do przebywania lub nawiedzania kobiet, nawet takich, co do których nie było podejrzeń, ale w danym przypadku mogło to wywołać zgorszenie lub stanowić jakieś zagrożenie dla duchownego. On także mógł zabraniać duchownym takiego przebywania lub nawiedzania ${ }^{14}$. Uprawnienie biskupa do wydawania norm w tej dziedzinie jest jego wyłącznym prawem i nie musi tego konsultować z radą kapłańską, prosząc o jej opinię - postulowano to w projektach tego kanonu, a ostatecznie nie zostało w nim zawarte ${ }^{15}$. Tadeusz Pawluk twierdzi, że „biskup diecezjalny w swoim zarządzeniu mógłby np. bliżej określić, jakimi przymiotami mają odznaczać się niewiasty wykonujące stałą posługę domową u duchownych"16.

Również niektóre synody diecezjalne w Polsce poruszają temat kontaktów duchownych z innymi osobami. W uchwałach Pierwszego Synodu Diecezji Kaliskiej znajdujemy polecenie, by duchowny, który zamierza odwiedzić krewnych lub znajomych w innej parafii, wcześniej osobiście lub telefonicznie powiadomił o tym jej proboszcza.

\footnotetext{
${ }^{12}$ Por. T. Pawluk, Prawo kanoniczne według Kodeksu Jana Pawła II, t. II: Lud Boży, jego nauczenie i uświęcanie, Olsztyn 1986, s. 92; J. KRukowski, Komentarz do kan. 277, w: Komentarz do Kodeksu Prawa Kanonicznego, t. II/1, ks. II: Lud Boży, red. J. Krukowski, Poznań 2005, s. 99.

${ }^{13} \mathrm{KPK}$, kan. 277 \$ 3.

${ }^{14} \mathrm{CIC}$, can. $133 \$ 3$ : „Iudicium an retinere vel frequentare mulieres, etiam illas in quas communiter suspicio non cadit, in peculiari aliquo casu scandalo esse possit aut incontinentiae afferre periculum, ad Ordinarium loci pertinet, cuius est clericos ab hac retentione vel frequentatione prohibere".

${ }^{15}$ Por. T. Ricón-PÉrez, Komentarz do kan. 277, w: Codex Iuris Canonici. Kodeks Prawa Kanonicznego. Komentarz, red. P. Majer, Kraków 2011, s. 260.

${ }^{16}$ T. Pawluk, Prawo kanoniczne według Kodeksu..., dz. cyt., s. 92.
} 
Wizyty takie winny mieć charakter duszpasterski i kapłański ${ }^{17}$. Z kolei Pierwszy Synod Diecezji Gliwickiej zawiera dokładne wytyczne dotyczące gospodyni. Czytamy w jego uchwałach: „Szczególną rolę wśród osób posługujących przy parafii pełni gospodyni. Nie powinna ona zamieszkiwać na plebanii, chyba że jest spokrewniona z proboszczem. W żadnym wypadku nie może być zameldowana na stałe na plebanii. Traci ona możliwość zamieszkania w budynku kościelnym z dniem utraty urzędu przez proboszcza. Każda gospodyni kończy swoją posługę w parafii $\mathrm{z}$ dniem utraty urzędu przez proboszcza lub administratora parafii"18. Warto także, jako kolejny przykład troski duchownych o wytrwanie w czystości i dobre imię, przytoczyć zapis Synodu Archidiecezji Warszawskiej: „Kapłani winni pielęgnować cnotę czystości, która w kapłańskim życiu realizowana jest w postaci celibatu. To obliguje kapłana do zachowania szczególnego dystansu w kontaktach z innymi osobami, a zwłaszcza wobec nieletnich i podwładnych. (...) Wykroczenie przeciw tej cnocie, po upomnieniu, będzie karane"19. Są także synody, które przypominają ogólnie, bez dosłownego zacytowania, normę kodeksową w tej materii ${ }^{20}$. Przepisy te mają więc chronić duchownych przed wywołaniem zgorszenia $\mathrm{z}$ powodu kontaktów w innymi osobami.

\section{Wykluczenie zgorszenia przy sprawowaniu Eucharystii w świątyni niekatolickiej}

Kolejną normą w Kodeksie prawa kanonicznego z 1983 roku, która ma zapobiec zgorszeniu, są przepisy dotyczące miejsca sprawowania sakramentu Eucharystii. W rozważanej materii istotny jest zapis: „Dla

\footnotetext{
${ }^{17}$ Por. Pierwszy Synod Diecezji Kaliskiej (2007-2009). Prawo diecezjalne Kościoła Kaliskiego, Kalisz 2009, stat. 282.

${ }^{18}$ Pierwszy Synod Diecezji Gliwickiej (2017-2018). Statuty i Aneksy, Gliwice 2018, stat. 162.

${ }^{19}$ IV Synod Archidiecezji Warszawskiej, Warszawa 2003, stat. 37.

${ }^{20}$ Zob. np. Kapłaństwo i życie konsekrowane jako wspólnota życia i posługi z Chrystusem, w: II Polski Synod Plenarny (1991-1999), Poznań 2001, nr 81; Synod Archidiecezji poznańskiej 2004-2008. Zwołany i przeprowadzony przez Arcybiskupa Stanisława Gądeckiego, t. II: Statuty, Poznań 2008, stat. 28.
} 
słusznej przyczyny i za wyraźną zgodą ordynariusza miejsca wolno kapłanowi sprawować Eucharystię w świątyni jakiegoś Kościoła lub wspólnoty kościelnej nie mającej pełnej jedności z Kościołem katolickim, z wykluczeniem zgorszenia"21. Poprzednio obowiązujący Kodeks jednoznacznie zabraniał kapłanowi katolickiemu sprawowania Eucharystii w świątyni heretyków lub schizmatyków, chociażby była ona kiedyś konsekrowana lub pobłogosławiona ${ }^{22}$. Aktualnie, mając na uwadze względy ekumeniczne ${ }^{23}$, odstąpiono od tak rygorystycznych przepisów ${ }^{24}$. Jest to możliwe, gdy spełnione będą równocześnie trzy warunki, zawarte w cytowanym kanonie. Mianowicie: musi istnieć do

\footnotetext{
${ }^{21} \mathrm{KPK}$, kan. 933.

${ }^{22}$ CIC, can. $823 \S 1$ : „Non licet Missam celebrare in templo haereticorum vel schismaticorum, etsi olim rite consecrato aut benedicto". Zgodnie z dawnym prawem, kościoły były albo konsekrowane, albo błogosławione. Aktualnie są albo poświęcane, albo błogosławione. Zob. KPK, kan. $1217 \$ \$ 1-2 ;$ Obrzędy poświęcenia kościoła i ołtarza, wyd. wzorcowe, Katowice 2001.

${ }^{23}$ Zagadnieniem tym zajął się Sobór Watykański II w dekrecie o ekumenizmie. Czytamy w nim między innymi: „Ponieważ obecnie w rozmaitych miejscach na ziemi pod natchnieniem Ducha Świętego przez modlitwę, słowo i działanie podejmowane są rozliczne wysiłki w celu zbliżenia się do owej pełnej jedności, jakiej chce Jezus Chrystus, obecny święty Sobór zachęca wszystkich wiernych Kościoła katolickiego, by rozpoznając znaki czasów, pilnie uczestniczyli w dziele ekumenicznym. Przez »ruch ekumeniczny« rozumie się działania i przedsięwzięcia podejmowane i stosownie do różnych potrzeb Kościoła i warunków chwili, ustanawiane w celu wspierania jedności chrześcijan, jak na przykład wszelkie wysiłki zmierzające do usunięcia słów, opinii i czynów, które w świetle sprawiedliwości i prawdy nie odpowiadałyby sytuacji odłączonych braci i z tej przyczyny utrudniały wzajemne stosunki z nimi; następnie »dialog « podjęty między biegłymi i odpowiednio wykształconymi ekspertami, prowadzony na zorganizowanych w duchu religijnym spotkaniach chrześcijan z różnych Kościołów lub Wspólnot; podczas owego dialogu każdy wyjaśnia głębiej naukę swej Wspólnoty i przejrzyście przedstawia jej szczególne znamiona”; Concilum VATICANum II, Decretum de oecumenismo Unitatis redintegratio, 21 listopada 1964, AAS 57 (1965), s. 90-112. Tekst polski: Soвór WATYкAŃSki II, Dekret o ekumenizmie Unitatis redintegratio, 21 listopada 1964, w: tenże, Konstytucje - Dekrety - Deklaracje, Poznań 2002, nr 4.

${ }^{24}$ Por. A. Mızıński, Communicatio in sacris w ustawodawstwie i praktyce Kościoła łacińskiego $w$ Polsce, $\mathrm{w}$ : Zagadnienia międzywyznaniowe w realizacji misji uświęcającej Kościoła, red. J. Krukowski, M. Sitarz, K. Dziub, Lublin 2010, s. 75-96.
} 
tego słuszna przyczyna, należy uzyskać wyraźną zgodę ordynariusza miejsca oraz być pewnym, że nie będzie to zgorszeniem.

Przed przybliżeniem tych trzech warunków wydaje się koniecznym wyjaśnienie, o jakie świątynie chodzi, albo precyzyjniej, jakie to Kościoły lub wspólnoty kościelne nie mają pełnej jedności z Kościołem katolickim. Krótko można powiedzieć, że te, które w widzialnym organizmie Kościoła nie są połączone „więzami wyznawania wiary, sakramentów i zwierzchnictwa kościelnego"25.

Pierwszy z wymienionych warunków to słuszna przyczyna. Tadeusz Pawluk, rozważając to zagadnienie, podkreśla, że „słuszną przyczynę zwykle stanowi konieczność zaradzenia potrzebom wiernych danej miejscowości, którzy nie mają w pobliżu własnego kościoła lub kaplicy"26. Dyrektorium ekumeniczne bardzo pozytywnie traktuje wspólne używanie świątyń ${ }^{27}$, a nawet ich budowanie ${ }^{28}$. Potrzeba sprawowania Eucharystii w takiej świątyni może także wystąpić w sytuacji zawierania małżeństwa mieszanego, jeśli z jakichś ważnych dla

${ }^{25}$ KPK, kan. 205. To nowy kanon w obecnym Kodeksie, niemający swojego odpowiednika w poprzednim. Jedynym jego źródłem jest: ConCILUM VATICANUM II, Constitutio dogmatica de Ecclesia Lumen gentium, 21 listopada 1964, AAS 57 (1965), s. 5-71. Tekst polski: SoвóR WAтүкаŃsкi II, Konstytucja dogmatyczna o Kościele Lumen gentium, 21 listopada 1964, w: tenże, Konstytucje - Dekrety - Deklaracje, dz. cyt., nr 14.

${ }^{26}$ Por. T. PAwluk, Sprawowanie Eucharystii według nowego Kodeksu Prawa Kanonicznego, Prawo Kanoniczne 30 (1987) nr 3-4, s. 27.

${ }^{27}$ Papieska Rada Ds. Jedności Chrześcijan, Dyrektorium ekumeniczne, 25 marca 1993, Międzynarodowy Przegląd Teologiczny Communio XIV (1994), nr 2 (dalej: DE), nr 138: „Z uwagi na rozwój społeczny, szybki wzrost ludności i urbanizację, a także ze względów finansowych tam, gdzie istnieją dobre kontakty ekumeniczne i wzajemne zrozumienie między wspólnotami, wspólne posiadanie czy użytkowanie miejsc kultu przez dłuższy okres może się okazać bardzo pożądane w praktyce".

${ }^{28}$ Tamże, nr 140: „Przed podjęciem planów wspólnej budowli, władze zainteresowanych wspólnot powinny uzgodnić najpierw sposób, w jaki ich różne zwyczaje i normy zostaną uszanowane, zwłaszcza w tym, co dotyczy sakramentów. Co więcej, należałoby dokonać umowy spisanej, wyrażającej jasno i adekwatnie wszystkie problemy, jakie mogą powstać w kwestii finansowej oraz w zakresie zobowiązań wynikających z praw kościelnych i cywilnych". 
siebie powodów nupturienci będą chcieli, by zaślubiny odbyły się w świątyni wyznania niekatolickiego, do którego należy jed no z nich. Do zawarcia małżeństwa w takim miejscu potrzebne będzie zezwolenie ordynariusza miejsca lub proboszcza ${ }^{29}$. Mowa tu oczywiście o sytuacji, kiedy wyrażana zgoda małżeńska będzie miała miejsce podczas Eucharystii, bo tylko taka nas tu interesuje, a celebransem będzie kapłan katolicki - ale wówczas kompetentny do udzielenia takiego zezwolenia nie będzie proboszcz, a jedynie ordynariusz miej$\mathrm{sca}^{30}$. Niemożliwa bowiem będzie koncelebra z kapłanem Kościoła lub wspólnoty kościelnej, do której świątynia ta należy. Wyraźnie zostało to podkreślone w Kodeksie prawa kanonicznego z 1983 roku $^{31}$. Czy daną przyczynę można uznać za słuszną, decyduje ordynariusz miejsca, nie zaś bezpośrednio zainteresowany kapłan. Marian Pastuszko zauważa, że czasem może wyniknąć różnica zdań pomiędzy ordynariuszem miejsca a proszącym o zezwolenie kapłanem. Ostateczną decyzję zawsze podejmuje ten pierwszy ${ }^{32}$.

\footnotetext{
${ }^{29} \mathrm{KPK}$, kan. $1118 \S 1$ : „Małżeństwo pomiędzy katolikami lub między stroną katolicką i niekatolicką ochrzczoną winno być zawierane w kościele parafialnym; w innym kościele lub kaplicy może być zawierane za zezwoleniem ordynariusza miejsca lub proboszcza”.

${ }^{30} \mathrm{DE}$, nr 159: „Ponieważ mogą się pojawić pewne problemy dotyczące udziału w Eucharystii, ze względu na obecność świadków lub zaproszonych na uroczystość niekatolików, małżeństwo mieszane, sprawowane zgodnie z formą katolicką, odbywa się na ogół poza liturgią eucharystyczną. Niemniej dla słusznych powodów biskup diecezji może pozwolić na sprawowanie Eucharystii. W tym ostatnim przypadku decyzję o dopuszczeniu, lub nie, niekatolickiej strony małżeństwa do komunii eucharystycznej winno się podjąć zgodnie z ogólnymi normami istniejącymi w tej dziedzinie, zarówno w odniesieniu do chrześcijan wschodnich, jak też do innych chrześcijan, uwzględniając przy tym tę szczególną sytuację przyjmowania sakramentu małżeństwa chrześcijańskiego przez dwie osoby ochrzczone”.

${ }^{31}$ KPK, kan. 908: „Katolickim kapłanom jest zabronione koncelebrowanie Eucharystii z kapłanami lub szafarzami kościołów lub wspólnot kościelnych nie mających pełnej wspólnoty z Kościołem katolickim”.

${ }^{32}$ Por. M. Pastuszko, Najświętsza Eucharystia według Kodeksu Prawa Kanonicznego Jana Pawła II, Kielce 1997, s. 321.
} 
Kolejnym warunkiem możliwości sprawowania Eucharystii w świątyni jakiegoś Kościoła lub wspólnoty kościelnej niemającej pełnej jedności z Kościołem katolickim jest uzyskanie wyraźnej zgody ordynariusza miejsca planowanej Eucharystii. Oznacza to, że taką prośbę - na przykład tak jak w omówionej wyżej sytuacji - winien skierować kapłan pragnący celebrować Eucharystię w takiej świątyni odpowiednio wcześniej. Zgoda musi być wyrażona w sposób wyraźny, czyli na piśmie lub słowami. Nie może być domniemana: gdyby kapłan przewidywał, że otrzyma takie pozwolenia, ale nigdy de facto o nie nie prosił. Sposób więc złożenia oświadczenia o wyrażeniu zgody oraz treść tego oświadczenia nie mogą budzić wątpliwości ${ }^{33}$. Z pewnością będzie to miało miejsce jedynie w sytuacji jednorazowej prośby. Gdy na stałe używa się świątyni niekatolickiej do sprawowania Eucharystii, wydaje się, że wystarczy ogólna zgoda ordynariusza miejsca dla każdego kapłana tam celebrującego. Wniosek taki można wyciągnąć z cytowanego już Dyrektorium ekumenicznego, poruszającego kwestie wspólnego używania miejsc kultu ${ }^{34}$. Należy tu jednak podkreślić, że zawsze musi to być świątynia chrześcijańska, gdyż instrukcja Redemptionis Sacramentum zabrania sprawowania Eucharystii w świątyni lub miejscu świętym jakiejkolwiek religii niechrześcijańskiej ${ }^{35}$.

W tym miejscu za Marianem Pastuszką można by jeszcze zapytać: Dlaczego kapłan w ogóle ma prosić ordynariusza o zezwolenie na taką celebrację? Kanonista ten odpowiada, że sprawowanie Eucharystii

\footnotetext{
${ }^{33}$ Tamże, s. 320.

${ }^{34} \mathrm{DE}$, nr 139: „Gdy biskup diecezji do tego upoważnił, zgodnie z normami podanymi ewentualnie przez Konferencję Episkopatu lub Stolicę Świętą, trzeba rozważyć starannie kwestię przechowywania Najświętszego Sakramentu, tak by uwzględnione zostały wytyczne zdrowej teologii sakramentalnej i zachowany został cały należny mu szacunek, przy równoczesnym uwzględnieniu różnorodności odczuć tych, którzy będą korzystali z danej świątyni, tworząc na przykład jakieś pomieszczenie osobne lub kaplicę".

${ }^{35}$ Por. Kongregacja Ds. Kultu Bożego i Dyscypliny Sakramentów, Instrukcja Redemptionis Sacramentum. O tym, co należy zachować, a czego unikać w związku z Najświętszą Eucharystią, 25 marca 2004, Poznań 2004, nr 109.
} 
w świątyni Kościoła lub wspólnoty kościelnej niemającej pełnej jedności z Kościołem katolickim ma znaczenie ekumeniczne, a działalność taka zawsze jest w kręgu zainteresowania tego przełożonego ${ }^{36}$.

Ostatnią z koniecznych przesłanek uznanych przez prawodawcę za warunek sine qua non odprawienia Mszy świętej w świątyni jakiegoś Kościoła lub wspólnoty kościelnej niemającej pełnej jedności z Kościołem katolickim jest wykluczenie zgorszenia, do którego mogłoby dojść tylko z tej przyczyny, że Eucharystia jest sprawowana w takim miejscu.

Odnosząc się do tej kwestii, należy przede wszystkim zastanowić się, jakie czynniki mogą determinować wystąpienie w tym przypadku zgorszenia. Marian Pastuszko zwraca tutaj uwagę na sytuację, że wierni katoliccy znają kapłana katolickiego, widzieli go sprawującego Eucharystię w świątyni katolickiej, a teraz widzą go robiącego to samo w świątyni akatolickiej. Kanonista dodaje, że „fakt ten może być dla nich przyczyną oddalenia się z prawej drogi życia i wejścia na drogę zła. Na tym polega zgorszenie. I do tego nie można dopuszczać"37. Może to także wywołać u wiernych swego rodzaju „indyferentyzm religijny"38. Przykład taki może bowiem spowodować, że będzie im obojętne, w jakiej świątyni będą oddawali Bogu kult. By zapobiec ewentualnemu zgorszeniu, kapłan winien wyjaśnić wiernym przyczyny celebrowania Eucharystii w świątyni innej niż katolicka oraz zasady, jakie determinują takie odstępstwo od normy. Na pewno

\footnotetext{
${ }^{36}$ Por. M. Pastuszko, Najświętsza Eucharystia..., dz. cyt., s. 320.

${ }^{37}$ Tamże, s. 321.

${ }^{38}$ J. MARIAŃSKI, Indyferentyzm religijny, w: Religia. Encyklopedia PWN, red. T. Gadacz, B. Milerski, t. 5, Warszawa 2002, s. 21: „Powstrzymywanie się od uznania określonej religii za prawdziwą oraz brak zainteresowania różnicami doktrynalnymi zachodzącymi między religiami”. Concilum Vaticanum II, Decretum de Ecclesiis Orientalibus Catholicis Orientalium Ecclesiarum, 21 listopada 1964, AAS 57 (1965), s 76-89. Tekst polski: Soвór WATYкAŃsкi II, Dekret o katolickich Kościołach wschodnich Orientalium Ecclesiarum, 21 listopada 1964, w: tenże, Konstytucje - Dekrety- Deklaracje, dz. cyt., nr 26: „Współuczestnictwo w czynnościach świętych, które przeszkadza jedności Kościoła albo kryje w sobie formalne trwanie w błędzie lub niebezpieczeństwo pobłądzenia w wierze, zgorszenia i indyferentyzmu, jest zakazane na mocy prawa Bożego".
} 
możliwość zaistnienia zgorszenia czy też chęć zapobieżenia mu będą kierowały ordynariuszem wydającym zgodę na taką celebrę ${ }^{39}$.

\section{Wykluczenie zgorszenia przy spowiedzi z udziałem tłumacza}

Prawodawca kodeksowy w księdze o uświęcającym zadaniu Kościoła w kan. 959-997 normuje zagadnienie sakramentu pokuty. W sakramencie tym „wierni wyznający uprawnionemu szafarzowi grzechy, wyrażający za nie żal i mający postanowienie poprawy, przez rozgrzeszenie udzielone przez tegoż szafarza otrzymują od Boga odpuszczenie grzechów po chrzcie popełnionych i jednocześnie dostępują pojednania z Kościołem, któremu grzesząc zadali ranę" ${ }^{40}$. Jedynym zwyczajnym sposobem spowiedzi i rozgrzeszenia jest spowiedź indywidualna ${ }^{41}$ : to znaczy, że w akcie tym nie uczestniczy nikt poza penitentem i spowiednikiem. Prawo Kościoła przewiduje tutaj jednak wyjątek: „Nikomu nie zabrania się spowiadać za pośrednictwem tłumacza, $\mathrm{z}$ wykluczeniem wszakże nadużyć i zgorszenia i z zachowaniem przepisu kan. 983, $\$ 2$ "42. Treść tego kanonu z jednej strony wydaje się jasna i czytelna, tak że niektóre komentarze do Kodeksu nie podają przy nim żadnego wyjaśnienia ${ }^{43}$, z drugiej zaś strony rodzą się jednak pytania, na przykład: Kto miałby w takiej sytuacji ulec zgorszeniu: tłumacz, inni penitenci? Albo co mogłoby być powodem zgorszenia? Na pewno nie można mieć wątpliwości co do tego, że spowiedź za pośrednictwem tłumacza jest prawem penitenta, a obowiązkiem spowiednika jest się na to zgodzić. To penitent decyduje, czy potrzebuje przy tym sakramencie skorzystać z pomocy tłumacza. Skoro tak, to jaka może być przyczyna tej nadzwyczajnej formy sprawowania sakramentu pokuty? Treść kanonu nie udziela na to odpowiedzi. Wydaje się, że najbardziej logiczną, choć tylko

\footnotetext{
${ }^{39}$ Por. M. Pastuszko, Najświętsza Eucharystia..., s. 321.

${ }^{40}$ KPK, kan. 959.

${ }^{41}$ Por. tamże, kan. 960.

${ }^{42}$ Tamże, kan. 990.

${ }^{43}$ Zob. np. T. Pawluk, Prawo kanoniczne wedtug Kodeksu..., dz. cyt., s. 413; por. T. Ricón-PÉrez, Komentarz do kan. 990, w: Codex Iuris Canonici. Kodeks Prawa..., dz. cyt., s. 740 .
} 
przykładową przyczyną jest nieznajomość przez spowiednika języka, którym posługuje się penitent. Może to być typowy język mówiony lub też język migowy, jeśli penitent jest głuchoniemy ${ }^{44}$.

$\mathrm{W}$ analizowanej tutaj sytuacji najistotniejsza kwestia to uniknięcie zgorszenia. W czasie spowiedzi tłumacz może bowiem uzyskać informacje, które mogą spowodować właśnie jego zgorszenie, czyli wejście na złą drogę życia i oddalenie się od dobrej. To jego ma zatem chronić zapis kanonu. Intencją prawodawcy jest, aby tłumacz nie ponosił w przyszłości konsekwencji zachowania penitenta, któremu udziela pomocy.

Zabezpieczeniem przed wystąpieniem zgorszenia będzie również norma kodeksowa, zgodnie z którą także tłumacz jest zobowiązany do zachowania w tajemnicy tego wszystkiego, czego dowiedział się podczas spowiedzi, w której pośredniczył. Choć jest to taki sam obowiązek jak spowiednika, to w jego przypadku prawodawca używa wyrażenia „sekret” (łac. secretum ${ }^{45}$ ), zaś przy spowiedniku „tajemnica” $\left(ł a c\right.$. sigillum $\left.{ }^{46}\right)$. Różnica jest również w sankcji karnej za naruszenie tej normy. Spowiednik zaciąga karę ekskomuniki latae sententiae zastrzeżonej Stolicy Apostolskiej ${ }^{47}$, tłumacz z kolei powinien być ukarany sprawiedliwą karą, nie wyłączając ekskomuniki ${ }^{48}$. Jak widać, jest to duża różnica. Gdyby nie było takiego zagrożenia karą dla tłumacza, ujawnienie przez niego wiedzy zdobytej na spowiedzi mogłoby doprowadzić innych wiernych do zgorszenia i naruszenia dobrego

\footnotetext{
${ }^{44}$ Por. P. Hemperek, Uświęcające zadanie Kościoła, w: Komentarz do Kodeksu Prawa Kanonicznego, t. 3, ks. III: Nauczycielskie zadanie Kościoła, ks. IV: Uświęcające zadanie Kościoła, Lublin 1986, s. 168; M. PAstuszko, Sakrament pokuty i pojednania, Kielce 1999, s. 518-519; J. KRUKowsKi, Komentarz do kan. 990, w: Komentarz do Kodeksu Prawa Kanonicznego, t. III/2, ks. IV: Uświecające zadanie Kościoła, red. J. Krukowski, Poznań 2011, s. 174.

${ }^{45} \mathrm{CIC}$, can. $983 \$ 2$ : „Obligatione secretum servandi tenentur quoque interpres, si detur, necnon omnes alii ad quos ex confessione notitia peccatorum quoquo modo pervenerit".

${ }^{46}$ CIC, can. $983 \$ 1$ : „Sacramentale sigillum inviolabile est; quare nefas est confessario verbis vel alio quovis et quavis modo de causa aliquatenus prodere penitentem".

${ }^{47}$ Por. KPK, kan. $1388 \$ 1$.

${ }^{48}$ Tamże, kan. $1388 \$ 2$.
} 
imienia penitenta, którego spowiedź ujawnił. To także osobno podlega karnej odpowiedzialności ${ }^{49}$.

\section{Zgorszenie a zachowanie tajemnicy o tajnym zawarciu małżeństwa}

Małżeństwo jest przymierzem, „przez które mężczyzna i kobieta tworzą ze sobą wspólnotę całego życia, skierowaną ze swej natury do dobra małżonków oraz do zrodzenia i wychowania potomstwa, zostało między ochrzczonymi podniesione przez Chrystusa Pana do godności sakramentu"50. Jego zawarcie nie jest prywatną sprawą narzeczonych, ale ma charakter społeczny, jest wydarzeniem we wspólnocie Kościoła ${ }^{51}$. Jednak „na skutek poważnej i naglącej przyczyny ordynariusz miejsca może zezwolić na tajne zawarcie małżeństwa" ${ }^{52}$. Oznacza to, że nikt nie będzie wiedział, że dane osoby zawarły związek małżeński. One same zachowują pełną dyskrecję o tym fakcie wobec postronnych ${ }^{53}$. Taki obowiązek spoczywa także na ordynariuszu miejsca, na asystującym przy jego zawieraniu, a także na świadkach ${ }^{54}$.

$\mathrm{Z}$ jakich powodów może być zawarte małżeństwo tajne? Kodeks krótko stwierdza, że wymaga to poważnej i naglącej przyczyny ${ }^{55}$. Z kolei Wojciech Góralski, na zasadzie przykładu, wylicza następujące racje: „potrzeba uspokojenia sumienia, gdy strony żyją

${ }^{49}$ Tamże, kan. $1390 \$ 2$ : „Kto składa przełożonemu kościelnemu inne oszczercze doniesienie o przestępstwie lub w inny sposób narusza czyjeś dobre imię, może być ukarany sprawiedliwą karą, nie wyłączając cenzury”. Kan. 200: „Nikomu nie wolno bezprawnie naruszać dobrego imienia, które ktoś posiada, ani też naruszać prawa każdej osoby do ochrony własnej intymności”.

${ }^{50}$ Tamże, kan. $1055 \S 1$.

${ }^{51}$ Por. PAPIESKa RAdA Do SPRAw Rodziny, Przygotowanie do sakramentu małzeństwa, 13 maja 1996, w: W trosce o dobro matżeństwa i rodziny. Dokumenty papieskiej rady ds. rodziny, t. I, red. M. Brzeziński, Lublin 2010, nr 55.

${ }^{52}$ KPK, kan. 1130.

${ }^{53}$ Por. W. Góralski, Komentarz do kan. 1130, w: Komentarz do Kodeksu Prawa Kanonicznego, t. III/2, ks. IV: Uświecające zadanie Kościoła, red. J. Krukowski, dz. cyt., s. 336.

${ }^{54}$ Por. KPK, kan. 1131 nr 2.

${ }^{55}$ Tamże, kan. 1130. 
w konkubinacie, a powszechnie uważani są za prawdziwych małżonków; bądź niebezpieczeństwo utraty przez strony podstawowych środków do życia z powodu ujawnienia faktu zawarcia przez nich małżeństwa” ${ }^{56}$. Jeszcze inne przykłady to „duża różnica w statusie społecznym małżonków, nierozumny sprzeciw krewnych, zakazy narzucone przez prawo cywilne (...), czyli sytuacje, w których brak celebracji małżeństwa $\mathrm{w}$ formie publicznej pociągałby za sobą niebezpieczeństwo grzesznego związku lub poważnych szkód moralnych bądź ekonomicznych" ${ }^{57}$.

Możliwość zawarcia tajnego małżeństwa bierze więc pod uwagę przesłanki pozytywne, czyli dobro osób. Może się jednak zdarzyć, że z ukrywania faktu zawarcia małżeństwa będzie wynikać zło, na przykład poważne niebezpieczeństwo zgorszenia, gdyż strony uchodziły w danym środowisku za konkubinat, lub też poważna szkoda, bo na przykład jeden z małżonków usiłował zawrzeć małżeństwo $\mathrm{z}$ inną osobą ${ }^{58}$. To tylko przykłady okoliczności, które, jeśli wystąpią, zwalniają ordynariusza z obowiązku zachowania tajemnicy o zawarciu małżeństwa. Kodeks prawa kanonicznego z 1983 roku w tej materii jest bardzo ogólny, gdyż nie podaje żadnych przykładów. Warto wspomnieć, że poprzednio obowiązujący Kodeks takowe wymieniał: gdy groziło jakieś zgorszenie lub ciężka zniewaga świętości małżeństwa, albo rodzice nie starali się o chrzest dzieci w takim małżeństwie zrodzonych, albo przy chrzcie nadali im fałszywe nazwiska, nie zawiadamiając w ciągu trzydziestu dni ordynariusza o zrodzonym i ochrzczonym potomstwie ze szczerym wskazaniem rodziców, albo zaniedbali chrześcijańskiego wychowania dzieci ${ }^{59}$.

\footnotetext{
${ }^{56}$ W. Góralski, Komentarz do kan. 1130, dz. cyt., s. 336. Zob. także: P.M. GajdA, Prawo małżeńskie Kościoła katolickiego, Tarnów 2000, s. 215-216.

${ }^{57}$ Por. J. Bernal Pascual, Komentarz do kan. 1130, w: Codex Iuris Canonici. Kodeks Prawa Kanonicznego. Komentarz, red. P. Majer, dz. cyt., s. 854.

${ }^{58}$ Por. W. Gór Alski, Komentarz do kan. 1130, dz. cyt., s. 337.

${ }^{59}$ CIC, can. 1106: „Huius permissionis obligatio ex parte Ordinarii non extenditur ad causam quo vel aliquod sacndalum aut gravis erga matrimonii sanctitatem iniuria ex secreti observantia immineat, vel parentes non curent filios ex tali matromonio susceptos baptizari aut eos baptizandos curent falsis expressis nominibus, quin
} 
Wobec tego, aktualnie ocena przyczyn powodujących ujawnienie faktu zawarcia małżeństwa, jak i sama decyzja o tym należeć będą do ordynariusza miejsca, który bierze pod uwagę nade wszystko zgorszenie, jakie mogłoby z tego wyniknąć ${ }^{60}$.

\section{Niebezpieczeństwo zgorszenia $z$ powodu pogrzebu jawnych grzeszników}

Zgodnie z Kodeksem prawa kanonicznego z 1983 roku, „pogrzeb kościelny, w którym Kościół wyprasza duchową pomoc zmarłym, okazuje szacunek ich ciału i równocześnie żywym niesie pociechę nadziei, należy odprawiać z zachowaniem przepisów liturgicznych"61. Jest on jednym z aktów kultu Bożego ${ }^{62}$.

Prawo do pogrzebu kościelnego jest jednym z praw osób należących do Kościoła katolickiego ${ }^{63}$. Co więcej, przysługuje ono także katechumenom ${ }^{64}$. Choć to określenie nie pada wprost, $\mathrm{z}$ brzmienia norm kodeksowych możemy wyczy tać, że jest to właśnie prawo. Nie jest ono jednak bezwzględne, gdyż Kodeks wymienia osoby, których pogrzebu kościelnego należy pozbawiać. „Jeśli przed śmiercią nie dali żadnych oznak pokuty, pogrzebu kościelnego powinni być pozbawieni: 1. notoryczni apostaci, heretycy i schizmatycy; 2. osoby, które wybrały spalenie swojego ciała $\mathrm{z}$ motywów przeciw wierze

interim Ordinarie intra triginta diec notitiam prolis susceptae et baptizatae cum sincera indicatione parentum praebeant, vel christianam filiorum educationem negligant".

${ }^{60}$ Por. KPK, kan. 1132.

${ }^{61}$ Tamże, kan. $1176 \S 2$.

${ }^{62}$ Zagadnienia związane z pogrzebem kościelnym zostały przez prawodawcę umieszczone w księdze czwartej Kodeksu prawa kanonicznego z 1983 roku: Uświęcające zadanie Kościoła, części drugiej: Pozostałe akty kultu Bożego, tytule trzecim: Pogrzeb kościelny. Zob. KPK, kan. 1176-1185.

${ }^{63}$ Por. KPK, kan. $1176 \$ 1$.

${ }^{64}$ Tamże, kan. $1183 \$ 1$. Kodeks z 1917 roku wprost wypowiadał się, że nieochrzczeni nie mogą otrzymać pogrzebu kościelnego. CIC, can. 1239 \$1: „Ad sepulturam ecclesiasticam non sunt admittendi qui sine baptismo decesserint". 
chrześcijańskiej; 3. inni jawni grzesznicy, którym nie można przyznać pogrzebu bez publicznego zgorszenia wiernych" 65 .

$\mathrm{W}$ interesującym nas tutaj temacie sposobów przeciwdziałania powstaniu zgorszenia należy zwrócić uwagę jedynie na ostatnią sytuację odmowy pogrzebu. Na początku należy zadać pytanie: Kogo prawodawca ma na myśli, określając niektórych wiernych „jawnymi grzesznikami"? Jednak trudno sobie wyobrazić stworzenie zamkniętego katalogu osób, które powinny być zaliczane do tej grupy. Stąd niemożliwe jest również wypracowanie reguły, którą należałoby stosować w odniesieniu do nich. Pewne istotne wskazówki dotyczące możliwości pozbawienia pogrzebu $\mathrm{z}$ uwagi na ryzyko zgorszenia zawiera Instrukcja liturgiczno-duszpasterska Episkopatu Polski o pogrzebie i modlitwach za zmarłych ${ }^{66}$. Wymienia ona wprost dwie grupy osób, wskazując jednocześnie warunki, jakie należy spełnić, by mogli otrzymać pogrzeb kościelny. Są to samobójcy i osoby, które do śmierci żyły w niesakramentalnym małżeństwie ${ }^{67}$.

O pierwszej z tych grup czytamy: „Według powszechnego zdania psychiatrów samobójcy nie są w pełni odpowiedzialni za swój czyn, dlatego nie można im odmawiać katolickiego pogrzebu, jeśli za życia okazywali przywiązanie do wiary i Kościoła" ${ }^{68}$. To ważna uwaga, gdyż w Kodeksie prawa kanonicznego z 1917 roku pogrzebu kościelnego byli pozbawieni ci, którzy zabili się po rozważnym przemyśleniu ${ }^{69}$. Wynika

\footnotetext{
${ }^{65} \mathrm{KPK}, \mathrm{kan} .1184 \$ 1$.

${ }^{66}$ Konferencja EPIsKopatu Polski, Instrukcja liturgiczno-duszpasterska o pogrzebie i modlitwach za zmartych, 5 maja 1978, w: Dokumenty Duszpastersko-Liturgiczne Episkopatu Polski (1996-1993), oprac. Cz. Krakowiak, L. Adamowicz, Lublin 1994, s. 351-357.

${ }^{67}$ Por. tamże, nr 13 i 15. Tutaj należy wyraźnie zaznaczyć, że owa instrukcja używa pojęcia „małżeństwo niesakramentalne”, które aktualnie wydaje się nieprawidłowe, gdyż każde małżeństwo ważnie zawarte przez chrześcijan jest małżeństwem sakramentalnym (zob. KPK, kan. $1055 \$ 2$ ). Dzisiaj na określenie takiego związku najczęściej używa się wyrażenia „związek niesakramentalny”.

${ }^{68}$ Konferencja EpISKopatu Polski, Instrukcja liturgiczno-duszpasterska Episkopatu o pogrzebie..., dz. cyt., nr 13.

${ }^{69} \mathrm{CIC}$, can. $1240 \$ 1, \mathrm{nr} 3$ : „Ecclesiastica sepultura privantur, nisi ante mortem aliqua dederint poenitentiae signa: Qui se ipsi occiderunt deliberato consilio”.
} 
z tego, że aby samobójstwo było powodem odmowy pogrzebu, musiało być popełnione z pełną przytomnością umysłu i całkowitą swobodą działania. Nie można go zatem było odmówić osobie, która działała w stanie zakłócenia czynności psychicznych czy chorej umysłowo, a fakt poczytalności musiał być pewnie stwierdzony. Podobnie nie można było odmówić kościelnego pochówku osobie, która tylko usiłowała popełnić samobójstwo ${ }^{70}$. Współcześnie samobójcy są uznawani za osoby z zaburzeniami psychicznymi i nie do końca odpowiadające za swój czyn. W związku z tym, jeśli za życia okazywali przywiązanie do wiary i Kościoła katolickiego, nie można odmówić im pogrzebu ${ }^{71}$.

We wspomnianej instrukcji nieco inaczej jest natomiast traktowany samobójca, który przed zamachem na własne życie dawał zgorszenie. Wówczas „należy [go] traktować jako jawnego grzesznika”72 i odmówić kościelnego pochówku ${ }^{73}$. W tym kontekście warto przytoczyć Deklarację Iura et bona Kongregacji Nauki Wiary: „Nie można zgodzić się na świadome pozbawienie się życia, czyli samobójstwo, podobnie jak na zabójstwo. Takie bowiem działanie człowieka zawiera w sobie odrzucenie najwyższej władzy Boga oraz Jego planu miłości. Jeśli chodzi o samobójstwo, to jest ono często również odrzuceniem miłości siebie samego, zaprzeczeniem naturalnego instynktu życia, ucieczką od obowiązków sprawiedliwości i miłości wobec bliźniego, różnych społeczności, czy wreszcie wspólnoty ludzkiej, chociaż - jak wiadomo - zdarzają się takie stany psychiczne, które zmniejszają lub eliminują winę"74.

\footnotetext{
${ }^{70}$ Por. F. BĄczkowicz, Prawo kanoniczne. Podręcznik dla duchowieństwa, t. II, Opole 1958, s. 410-411.

${ }^{71}$ Por. T. ŚLIPKo, Etyczny problem samobójstwa, Kraków 2008, s. 40-41; M. STOKŁosA, Prawo do katolickiego pogrzebu w niektórych wyjątkowych okolicznościach, Prawo Kanoniczne 53 (2010) nr 3-4, s. 89-90.

${ }^{72}$ Konferencja Episkopatu Polski, Instrukcja liturgiczno-duszpasterska Episkopatu o pogrzebie..., dz. cyt., nr 13

${ }^{73}$ Por. M. StokŁosa, Prawo do katolickiego pogrzebu..., dz. cyt., s. 92-93.

${ }^{74}$ Kongregacja Nauki Wiary, Deklaracja Iura et bona, 5 maja 1980, w: W trosce o pełnię wiary. Dokumenty Kongregacji Nauki Wiary 1966-1994, tłum. i oprac. Z. Zimowski, J. Królikowski, Tarnów 1995, nr 1.
} 
Do kolejnej grupy jawnych grzeszników, którym należy odmówić pogrzebu katolickiego, zaliczyć można osoby, które żyły w związku niesakramentalnym, przez co wywoływały publiczne zgorszenie ${ }^{75}$. Kodeks prawa kanonicznego z 1917 roku zaliczał je do publicznych i jawnych grzeszników ${ }^{76}$. Franciszek Bączkowicz w komentarzu do tego Kodeksu napisał, że do kategorii tej należą między innymi osoby, które żyły w konkubinacie, bigamiści i osoby złączone tylko związkiem cywilnym ${ }^{77}$. To było powodem odmówienia im katolickiego pochówku. Aktualnie sytuacja ta zmieniła się o tyle, że na pierwszy plan wysunięto postawę takich osób za życia, ich stosunek do wiary i Kościoła, i to decyduje o pogrzebie katolickim bądź odmówieniu go. Trzeba tutaj zaznaczyć, że już w roku 1973 Kongregacja Nauki Wiary złagodziła normę kanonu 1240 poprzedniego Kodeksu, informując, że „możliwie szybko zostanie ogłoszony nowy przepis, w którym nie będzie już zabroniona celebracja pogrzebu religijnego tym wiernym, którzy przed śmiercią znajdowaliby się w sytuacji umożliwiającej ujawnienie grzechu, zachowali łączność z Kościołem i dali jakieś oznaki pokuty, byle uniknąć zgorszenia innych wiernych"78.

Zgodnie z wytycznymi Kościoła, odmowa w takich sytuacjach winna należeć do rzadkości. Postulat ten jest warunkowany faktem, że „Kościół nie rozstrzyga o losie osoby zmarłej, pogrzeb zaś posiada charakter modlitwy wstawienniczej za zmarłego. Wypada więc jak najrzadziej odmawiać pogrzebu kościelnego, ograniczając się tylko do wypadków koniecznych, wziąwszy pod uwagę odnośne dyspozycje prawa powszechnego i nieusuwalne publiczne zgorszenie wiernych"79.

\footnotetext{
${ }^{75}$ Konferencja Episkopatu Polski, Instrukcja liturgiczno-duszpasterska Episkopatu o pogrzebie..., dz. cyt., nr 15.

${ }^{76} \mathrm{CIC}$, can. $1240 \$ 1$, nr 6: „Ecclesiastica sepultura privantur, nisi ante mortem aliqua dederint poenitentiae signa: aliis peccatores publici et manifesti”.

${ }^{77}$ Por. F. BĄczkowicz, Prawo kanoniczne. Podręcznik..., dz. cyt., s. 411-412.

${ }^{78}$ Kongregacja Nauki Wiary, List o pogrzebie kościelnym Complures Conferentiae, 29 maja 1973, w: W trosce o petnię wiary. Dokumenty Kongregacji Nauki Wiary 1966-1994, dz. cyt., s. 53.

${ }^{79}$ Uchwały Pierwszego Synodu Diecezji Toruńskiej. Prawo partykularne Kościoła Toruńskiego, Toruń 2011, stat. $334 \$ 2$.
} 
Udzielenie więc pogrzebu kościelnego jawnemu grzesznikowi jest możliwe po spełnieniu łącznie dwóch przesłanek. Po pierwsze, musi on przed śmiercią dać znak pokuty. Po wtóre, musi zachodzić pewność, że pogrzeb takiej osoby nie spowoduje zgorszenia wiernych. Jak czytamy w instrukcji o pogrzebie i modlitwach za zmarłych, „do znaków pokuty, które uprawniają do chrześcijańskiego pogrzebu - a których istnienie potwierdzają wiarygodni świadkowie - należą: prośba o kapłana (choćby nie zdążył przybyć), wzbudzenie zewnętrzne aktu żalu, np. przez bicie się w piersi, ucałowanie krzyża, przeproszenie za dane zgorszenie itp. Publiczne zgorszenie wyklucza się przez to, że wiernych informuje się o tych znakach pokuty"s0. Instrukcja ta w swojej treści odwołuje się do dekretu Kongregacji Nauki Wiary z 20 września 1973 roku, która już wtedy pozwalała na katolicki pogrzeb jawnych grzeszników, „jeżeli przed śmiercią dali jakieś oznaki pokuty i wyklucza się publiczne zgorszenie innych wiernych"\$1. Możliwość udzielenia pogrzebu kościelnego bez ryzyka zgorszenia wiernych jest mocno zaakcentowana w polskim ustawodawstwie synodalnym ${ }^{82}$.

\section{Zachowanie sekretu w procesie karnym i spornym}

Prawodawca kodeksowy zabezpiecza także niebezpieczeństwo powstania zgorszenia podczas procesu karnego lub spornego, co omawia norma kanonu 1455 . W przepisie tym akcent został położony na zachowanie tajemnicy (takiego pojęcia używa polskie wydanie Kodeksu prawa kanonicznego z 1983 roku, choć $\mathrm{w}$ wersji oryginalnej widnieje wyrażenie secretum ${ }^{83}$ ). Tajemnica ta „to tzw. tajemnica urzędowa lub

\footnotetext{
${ }^{80}$ Konferencja Episkopatu Polski, Instrukcja liturgiczno-duszpasterska o pogrzebie..., dz. cyt., nr 14.

${ }^{81}$ Kongregacja Nauki Wiary, Dekret o pogrzebie Patres Sacrae Congregationis, 20 września 1973, w: W trosce o petnię wiary. Dokumenty Kongregacji Nauki Wiary 1966-1994, dz. cyt., s. 65.

${ }^{82}$ Zob. M. SAJ, Zgorszenie jako przyczyna odmowy pogrzebu kościelnego w świetle uchwał polskich synodów diecezjalnych, Studia Włocławskie 21 (2019), s. 455-468.

${ }^{83} \mathrm{CIC}$, can. 1455: „\$1. In iudicio poenali semper, in contentioso autem si ex revelatione alicuius actus processualis praeiudicium partibus obvenire possit, iudices
} 
zawodowa. (...) powierzona jest $\mathrm{z}$ wprost lub domyślnie wyrażonym warunkiem jej dochowania" ${ }^{4}$. W procesie karnym obowiązuje ona zawsze, bo dotyczy interesów publicznych, zaś w procesie spornym, który dotyczy interesów prywatnych ${ }^{85}$, wtedy, gdy „z wyjawienia jakiegoś aktu procesowego może wyniknąć szkoda dla stron"86. Jest o niej mowa w każdym z trzech paragrafów wspomnianego kanonu. Tajemnicę mają zachować sędziowie i pomocnicy trybunału ${ }^{87}$, innych zaś - świadków, biegłych, strony, ich adwokatów lub pełnomocników - można do tego zobowiązać, „ilekroć charakter sprawy lub dowodów jest taki, że z rozpowszechnienia akt lub dowodów zagrożona byłaby sława innych lub mogłaby powstać przyczyna nieporozumień lub zgorszenie" 88 . Generalnie zatem prawodawca nie zobowiązuje ich do zachowania tajemnicy w procesach spornych, przewidując jednak możliwość wystąpienia wspomnianych sytuacji, sędzia może od nich tego wymagać. Jest to zrozumiałe, gdyż uczestnicy procesów, szczególnie karnych, mają nieznaną innym wiedzę o życiu stron i dobrze by było, ze względu na ich dobro, by ta wiedza nie stała się publiczna. Właśnie z jej ujawnienia mogłoby wyniknąć zgorszenie: ktoś mógłby o takiej osobie zmienić dobre zdanie, które dotąd o niej miał. Choć przepis ten wprost odwołuje się do procesu karnego i spornego, to - zdaniem Tadeusza Pawluka - „niekiedy może mieć zastosowa-

et tribunalis adiutores tenentur ad secretum officii servandum. $\$ 2$. Tenentur etiam semper ad secretum servandum de discussione quae inter iudices in tribunali collegiali ante ferendam sententiam habetur, tum etiam de variis suffragiis et opinionibus ibidem prolatis, firmo praescripto can. $1609, \S 4$. $\$ 3$. Immo, quoties natura causae vel probationum talis sit ut ex actorum vel probationum evulgatione aliorum fama periclitetur, vel praebeatur ansa dissidiis, aut scandalum aliudve id genus incommodum oriatur, iudex poterit testes, peritos, partes earumque advocatos vel procuratores iureiurando astringere ad secretum servandum".

${ }^{84}$ L. Del Amo, Komentarz do kan. 1130, w: Codex Iuris Canonici. Kodeks Prawa Kanonicznego. Komentarz, red. P. Majer, dz. cyt., s. 1095.

${ }^{85}$ Por. tamże; J. Krukowsкi, Komentarz do kan. 1455, w: Komentarz do Kodeksu Prawa Kanonicznego, t. V, ks. VII: Procesy, red. J. Krukowski, Poznań 2007, s. 79-80.

${ }^{86} \mathrm{KPK}$, kan. $1455 \$ 1$.

${ }^{87}$ Por. tamże, kan. $1455 \$ \$ 1-2$.

${ }^{88}$ Tamże, kan. $1455 \S 3$. 


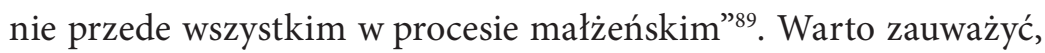
że art. 73 instrukcji procesowej Dignitas connubii ${ }^{90} \mathrm{w}$ dużej mierze zbudowany jest właśnie z treści analizowanego tutaj kanonu 1455, związanego z głównym zagadnieniem prowadzonych rozważań.

\section{Zapobieżenie zgorszeniu przy przesłuchiwaniu świadków}

W funkcjonujących w kanonicznym porządku prawnym procesach przewidziany jest udział świadków ${ }^{91}$. To ważny element procesowy, gdyż „świadek jest źródłem dowodu, a jego zeznanie środkiem dowodowym" 92 . Świadkiem jest więc osoba fizyczna wezwana przez uprawniony organ do stawiennictwa i złożenia zeznania w postępowaniu toczącym się przed tym organem ${ }^{93}$. Definicja w ujęciu prawnym określa świadka jako osobę, która poznała zdarzenie bądź okoliczności za pomocą swoich zmysłów i została powołana przez

${ }^{89}$ T. Pawluk, Prawo kanoniczne według Kodeksu Jana Pawła II, t. 4: Doczesne dobra Kościoła. Sankcje w Kościele. Procesy, Olsztyn 1990, s. 213.

${ }^{90}$ Pontificium Consilium de Legum Textibus Interpretandis, Instructio Dignitas connubii servanda a tribunalibus dioecesanis et interdioecesanis in pertractandis causis nullitatis matrimonii, Roma 2005. Tekst polski w: Komentarz do instrukcji procesowej „Dignitas connubii”, red. T. Rozkrut, Sandomierz 2007 (dalej: DC), art. 73: „\$1. Sędziowie i inni urzędnicy oraz pomocnicy sądu zobowiązani są do zachowania tajemnicy urzędowej (por. kan. 1455, \$1). \$2. Sędziowie szczególnie są zobowiązani do zachowania tajemnicy dotyczącej dyskusji, która ma pośród nich miejsce w trybunale kolegialnym przed wydaniem wyroku, a także przedstawionych podczas niej różnych głosów i opinii, z zachowaniem art. 248, $\$ 4$ (por. kan. $1455, \S 2)$. $\$ 3$. Ilekroć charakter sprawy lub dowodów jest taki, że rozpowszechnienie akt lub dowodów zagrażałoby sławie innych albo mogłoby być przyczyną nieporozumień lub zgorszenia, lub innych podobnych niedogodności, sędzia może zobowiązać świadków, biegłych, strony i ich adwokatów lub pełnomocników do zachowania tajemnicy specjalną przysięgą albo, jeśli wymaga tego przypadek, co najmniej przyrzeczeniem, z zachowaniem art. 159, 229-230 (por. kan. 1455, § 3)”.

${ }^{91}$ Zob. KPK, kan. 1547-1573; DC, s. 268-278, art. 193-202.

${ }^{92}$ Świadek, w: Encyklopedia popularna PWN, red. B. Kaczorowski, Warszawa 2010, s. 998.

${ }^{93}$ Por. M. Sitarz, Słownik prawa kanonicznego, Warszawa 2004, s. 174; Świadek, w: Nowa encyklopedia powszechna, red. B. Petrozolin-Skowrońska, t. 6, Warszawa 1997, s. 259. 
sąd, w celu złożenia zeznań dotyczących okoliczności rozpatrywanej sprawy $^{94}$. Z kolei świadkiem w znaczeniu procesowym, czyli ścisłym, jest osoba niebędąca stroną sporu, która może dostarczyć sędziemu obiektywnych informacji o faktach lub okolicznościach mogących mieć wpływ na rozpoznanie i rozstrzygnięcie sprawy ${ }^{95}$. Źródłem informacji przedstawionych sądowi przez świadka winny być tylko jego spostrzeżenia, a nie jego wiedza i przekonania ${ }^{96}$.

Taka definicja zakłada, że świadek powinien być osobą wiarygodną i mającą coś ważnego do powiedzenia w danej sprawie ${ }^{97}$. Świadkowie są mniej obiektywnym środkiem dowodowym niż dokumenty, lecz w praktyce sądowej częściej wykorzystywanym. Przy zeznaniach świadka należy brać pod uwagę nie tylko przekazane informacje, lecz także samą osobę zeznającego, jego wiarygodność, spostrzeżenia, zdolność opowiedzenia o widzianych i słyszanych faktach ${ }^{98}$ - twierdzi Ryszard Sztychmiler.

Zeznania świadków podlegają swobodnej ocenie sędziego. Należy w niej uwzględnić kryteria osobowe, takie jak stan osoby i jej uczciwość, podstawę zeznań, stałość i konsekwentność, świadectwa kwalifikacyjne oraz kryteria przedmiotowe, czyli istnienie albo brak współświadków, potwierdzenie zeznania przez inne elementy dowodowe ${ }^{99}$.

\footnotetext{
${ }^{94}$ Por. M. Greszata-Telusiewicz, Świadek, w: Encyklopedia katolicka, t. 19, red. E. Gigilewicz, Lublin 2014, s. 312-313.

${ }^{95}$ Por. R. Sztychmiler, Przesłuchanie świadków w procesie kanonicznym w: Dowodzenie w procesach kościelnych, red. J. Krzywkowska, R. Sztychmiler, Olsztyn 2014, s. 47.

${ }^{96}$ Por. tenże, Powoływanie świadków w procesie kanonicznym, w: Księga Jubileuszowa Profesora Tadeusza Smyczyńskiego, Toruń 2008, s. 835.

${ }^{97}$ Por. M. BARtoszeK, Nova causae propositio $w$ Kodeksie Prawa Kanonicznego z 1983 roku i Instrukcji Procesowej Dignitas Connubi, Kościół i Prawo 3 (16) (2014), nr 2, s. 153.

${ }^{98}$ Por. R. Sztychmiler, Proces sporny, w: Komentarz do Kodeksu Prawa Kanonicznego, t. V, ks. VII: Procesy, red. J. Krukowski, dz. cyt., s. 199.

${ }^{99}$ Por. KPK, kan. 1572.
} 
Zasadniczo zeznanie jednego świadka nie stanowi wystarczającego środka dowodowego ${ }^{100}$, zgodnie z łacińską paremią: Testis unus testis nullus - jeden świadek to żaden świadek, dlatego powinno ich być więcej ${ }^{101}$. Kodeks wskazuje, że „świadkowie powinni być przesłuchiwani osobno i pojedynczo"102, co ma zapewnić większą wiarygodność i obiektywność ich zeznań. Wtedy bowiem żaden z nich nie kieruje się wypowiedziami innych, ale przedstawia tylko własne spostrzeżenia. By to zapewnić, sędzia zobowiązuje każdego z nich, żeby w żaden sposób nie informowali pozostałych o treści swojego przesłuchania $^{103}$. Zeznanie danego świadka winno być potwierdzone przez zeznania innego lub przez inny środek dowodowy. Należy je zatem ocenić w kontekście zeznań pozostałych świadków ${ }^{104}$. Może się jednak zdarzyć, że zeznania poszczególnych świadków dotyczące danego zdarzenia wykluczają się. W takiej sytuacji istnieje możliwość konfrontacji, nie tylko świadków, ale także świadka ze stroną procesową. W Kodeksie czytamy bowiem: „Jeśli świadkowie nie zgadzają się, między sobą lub ze stroną, w rzeczy poważnej, sędzia może zgromadzić i skonfrontować różniących się między sobą, tak by uniknąć, o ile to możliwe, kłótni i zgorszenia"105. Ponieważ konfrontacja jest szczególnym i wyjątkowym środkiem dowodowym, sędzia może ją zarządzić tylko w razie istotnej sprzeczności zeznań, które dotyczą

\footnotetext{
100 Tamże, kan. 1573: „Zeznanie jednego świadka nie może być pełnym dowodem, chyba że chodzi o świadka kwalifikowanego, który zeznaje o sprawach dokonanych z urzędu, albo okoliczności rzeczy lub osób sugerują inaczej”. Instrukcja procesowa Dignitas connubii w temacie tym dosłownie przytacza ten kanon w art. 202. Zob. DC, s. 277.

${ }^{101}$ Sentencje łacińskie, wybór i oprac. J. Syjud, Katowice 2003, s. 152.

${ }^{102} \mathrm{KPK}$, kan. $1560 \$ 1$. Taki sam wymóg zawarty był w poprzednio obowiązującym Kodeksie prawa kanonicznego: „Testes seorsum singuli examinandi sunt”; CIC, can. $1772 \S 1$.

${ }^{103}$ Por. R. Sztychmiler, Proces sporny, dz. cyt., s. 213; J. Calvo-Ảlvarez, Komentarz do kan. 1560, w: Codex Iuris Canonici. Kodeks Prawa Kanonicznego. Komentarz, red. P. Majer, dz. cyt., s. 1173.

${ }^{104}$ Por. T. Pawluk, Prawo kanoniczne według Kodeksu Jana Pawła II, t. 4: Doczesne dobra Kościoła. Sankcje..., dz. cyt., s. 273-275.

${ }^{105} \mathrm{KPK}$, kan. $1560 \$ 2$; por. CIC, can. $1772 \$ \$ 2-3$.
} 
faktów mających duże znaczenie dla właściwego wyjaśnienia sprawy. „Konfrontacja nie jest potrzebna, jeśli nie ma poważnych różnic między zeznającymi" ${ }^{106}$. Tadeusz Pawluk poleca, by przeprowadzić ją umiejętnie i taktownie. Należy bezwzględnie unikać kłótni osób konfrontowanych lub gorszących zajśćc ${ }^{107}$.

W rozważanym w niniejszej pracy temacie najważniejsza jest właśnie konfrontacja, a nade wszystko sposób jej przeprowadzenia. Istotne są jakby jej warunki podane przez prawodawcę: należy uniknąć jeśli to możliwe - kłótni i zgorszenia. Żaden jednak z przywołanych autorów nie wyjaśnia bliżej, na czym zgorszenie mogłoby polegać. Na pewno chodzi o różnice zeznań. Każda ze stron może mocno obstawać przy swojej wersji, do tego stopnia, że będą się ze sobą kłócić. Dojście do prawdy o przestępstwie w procesie karnym, a o to w nim przecież chodzi, nie może odbywać się w takiej atmosferze. Z pewnością gorszące byłoby, gdyby po takiej konfrontacji świadkowie lub świadek i strony odeszli skłóceni, poróżnieni, pogniewani. Mogłoby się także zdarzyć, że jeden ze świadków uzyskałby jakąś negatywną informację o stronie, której wcześniej nie posiadał. To także mogłoby go zgorszyć, strona straciłaby w jego oczach. To właśnie winien mieć na uwadze sędzia, decydując się na konfrontację ze wskazanymi osobami. Jest ona bowiem przysługującą mu możliwością, co podkreśla kanon wyrażeniem „sędzia może”, to znaczy nie musi z niej skorzystać, zwłaszcza wtedy, gdyby przewidywał negatywne jej skutki $\mathrm{w}$ postaci zgorszenia.

\section{Zapobiegawcze zarządzenia ordynariusza}

W toczącym się procesie sądowym w sprawie karnej ordynariuszowi przysługują określone w prawie kompetencje. Jedna z nich zawarta jest w kanonie 1722, gdzie czytamy: „Celem uniknięcia zgorszenia, ochrony wolności świadków i gwarancji wymiaru

\footnotetext{
${ }^{106}$ J. Calvo-Álvarez, Komentarz do kan. 1560, w: Codex Iuris Canonici. Kodeks..., dz. cyt., s. 1173.

${ }^{107}$ Por. T. Pawluk, Prawo kanoniczne według Kodeksu Jana Pawła II, t. 4: Doczesne dobra Kościoła. Sankcje..., dz. cyt., s. 269; DC, art. $165 \$ 2$, s. 243.
} 
sprawiedliwości, ordynariusz, po wysłuchaniu rzecznika sprawiedliwości i wezwawszy samego oskarżonego, może, w jakimkolwiek stadium procesu, oddalić oskarżonego od świętej posługi lub jakiegoś urzędu i zadania kościelnego, oraz nakazać lub zakazać pobytu w jakimś miejscu lub terytorium, a nawet zabronić publicznego uczestnictwa w Najświętszej Eucharystii; wszystko to, po ustaniu przyczyny, należy odwołać, ma to też swój kres, na mocy samego prawa, z ustaniem procesu karnego". Dyspozycje te obecne były również w poprzednio obowiązującym Kodeksie prawa kanonicznego. Są one nawet jedynym źródłem obecnej normy ${ }^{108}$. Należy podkreślić, że konieczność zastosowania przez ordynariusza tych zapobiegawczych środków nie stoi w sprzeczności z tym, że podejrzany do czasu udowodnienia mu winy korzysta $\mathrm{z}$ domniemanej niewinności ${ }^{109}$.

Jak łatwo zauważyć, prawodawca daje te kompetencje ordynariuszowi, nie zaś sędziemu, ale pod konkretnymi warunkami, wymienionymi w cytowanym kanonie: gdy wysłucha rzecznika sprawiedliwości i wezwie oskarżonego. Dopiero potem może zastosować względem drugiego wymienione ograniczenia. Na marginesie warto podkreślić, iż nie można ich nazwać karami ${ }^{110}$, gdyż proces jeszcze się nie zakończył, a w niektórych przypadkach nawet nie rozpoczął. Oznacza to, że gdyby oskarżony, na przykład duchowny, nie zastosował się do nich, wówczas podjęte przez niego akty byłyby ważne, ale niegodziwe ${ }^{111}$.

Jednym z celów zastosowania tych ograniczeń jest zapobieżenie zgorszeniu. Można tutaj zapytać: Czy i dlaczego mogłoby wyniknąć zgorszenie, gdyby nie zastosowano tych środków? Oskarżonemu

\footnotetext{
${ }^{108}$ Zob. CIC, can. 1956-1958.

${ }^{109}$ Por. S. ŁUPIŃski, Zapobiegawcze zarządzenia ordynariusza wobec oskarżonego, Studia Teologiczne 15 (1997), s. 203-207.

${ }^{110}$ J. KRukowski, Komentarz do kanonu 1722, w: Komentarz do Kodeksu Prawa Kanonicznego, t. V, ks. VII: Procesy, red. J. Krukowski, dz. cyt., s. 410: „Ograniczenia względem osoby oskarżonego nie mają charakteru karnego, ale administracyjno-zapobiegawczy przed utrudnianiem przebiegu procesu”. Por. F. LozA, Komentarz do kan. 1722, w: Codex Iuris Canonici. Kodeks Prawa Kanonicznego. Komentarz, red. P. Majer, dz. cyt., s. 1294.

${ }^{111}$ Zob. KPK, kan. 1338 \$\$ 1-3.
} 
postawiono konkretne zarzuty, jest oskarżony o popełnienie przestępstwa, zatem brak reakcji kościelnej władzy już na tym etapie mógłby wskazywać, że nic ona w tym zakresie nie czyni. Tadeusz Pawluk podkreśla, że takie zarządzenia ordynariusza „mogą się okazać konieczne tylko przy cięższych przestępstwach”112.

Prawodawca kodeksowy w zastosowaniu tych środków widzi nie tylko sposób na uniknięcie zgorszenia, ale także na to, by ochronić wolność świadków i gwarantować wymiar sprawiedliwości. Dlatego mogą one być użyte na każdym etapie procesu, co więcej, także przed jego formalnym wszczęciem, czyli na etapie wstępnego dochodzenia ${ }^{113}$, które nie należy sensu stricto do procesu ${ }^{114}$. Nieco innego zdania jest Józef Krukowski, który twierdzi, że decyzję taką ordynariusz może „podjąć już po zainicjowaniu procesu sądowego w sprawie karnej”115. $\mathrm{W}$ podobnym duchu wypowiada się inny kanonista, Zbigniew Suchecki: „Ordynariusz (...) może w jakimkolwiek stadium procesu oddalić oskarżonego od świętej posługi (...)"116. Stanowisko takie nie jest oczywiście błędem, gdyż tak wynika z normy kodeksowej. Jednak na możliwość wcześniejszego wprowadzenia tych ograniczeń wskazuje Kongregacja Nauki Wiary w swoich normach dotyczących cięższych przestępstw ${ }^{117}$, a także Konferencja Episkopatu Polski

112 T. Pawluk, Prawo kanoniczne według Kodeksu Jana Pawła II, t. 4: Doczesne dobra Kościoła. Sankcje..., dz. cyt., s. 384.

${ }^{113} \mathrm{KPK}$, kan. 1717 \$1: „Ilekroć ordynariusz otrzyma przynajmniej prawdopodobną wiadomość o przestępstwie, powinien sam lub przez inną odpowiednią osobę ostrożnie zbadać fakty i okoliczności oraz poczytalność, chyba że takie dochodzenie wydaje się zupełnie zbędne".

${ }^{114}$ Tamże, kan. $1718 \$ 1$ : „Kiedy elementy wydają się wystarczająco zebrane, ordynariusz winien zadecydować: 1 czy może być wszczęty proces w celu wymierzenia albo deklarowania kary; 2 czy to, biorąc pod uwagę kan. 1341, jest wskazane; 3 czy należy zastosować proces sądowy, czy - jeżeli ustawa nie zabrania - należy się posłużyć dekretem pozasądowym”.

${ }^{115}$ J. Krukowski, Komentarz do kanonu 1722, dz. cyt., s. 410.

${ }^{116}$ Z. SUCHECKI, Wydalanie duchownych na podstawie kanonicznego procesu karnego, Prawo Kanoniczne 54 (2011) nr 3-4, s. 107-108.

${ }^{117}$ Por. Congregatio pro Doctrina Fidei, Normae de delictis Congregationi pro Doctrina Fidei reservatis seu Normae de delictis contra fidem necnon degravioribus 
w wytycznych dotyczących wstępnego dochodzenia kanonicznego w przypadku oskarżeń duchownych o czyny przeciwko szóstemu przykazaniu Dekalogu z osobą niepełnoletnią poniżej osiemnastego roku życia ${ }^{118}$. Można więc powiedzieć, że w decyzji takiej przejawia się troska prawodawcy kościelnego o zapobieżenie zgorszeniu. Gdy ustanie przyczyna zastosowania owych zakazów, winny być one odwołane, zaś po zakończeniu procesu ustają z mocy samego prawa. Wówczas nie będzie już zagrożenia wystąpienia zgorszenia, gdyż oskarżony będzie oczyszczony z zarzutów albo zostanie nań nałożona kara za popełnione przestępstwo.

delictis, 25 maja 2010, AAS 102 (2010), art. 19. Tekst polski: KongregaCja NAUKI Wiary, Normae de gravioribus delictis, 21 maja 2010, „L'Osservatore Romano” (wyd. pol.) 10 (2010), art. 19: „Przy utrzymaniu w mocy prawa ordynariusza lub hierarchy - od samego początku dochodzenia wstępnego - do nakazania tego, co jest postanowione w kan. 1722 Kodeksu Prawa Kanonicznego lub w kan. 1473 Kodeksu Kanonów Kościołów Wschodnich, także wyznaczony przewodniczący trybunału, na wniosek rzecznika sprawiedliwości, ma tę samą władzę pod tymi samymi warunkami, określonymi przez wspomniane kanony".

${ }^{118}$ Konferencja Episkopatu Polski, Wytyczne dotyczace wstępnego dochodzenia kanonicznego w przypadku oskarżeń duchownych o czyny przeciwko szóstemu przykazaniu dekalogu z osoba niepetnoletnia poniżej osiemnastego roku życia. Uchwała nr 14/384/2019 Konferencji Episkopatu Polski z dnia 8 października 2019, w: http:// bit.ly/pk2019-3-1 (dostęp 1.04.2020), nr 7: „Jeśli ujawnione fakty dotyczyłyby bieżących wydarzeń i wydawały się prawdopodobne, ordynariusz ma prawo do nakazania tego, co jest postanowione w kan. 1722 Kodeksu Prawa Kanonicznego. Jeżeli natomiast ujawnione fakty dotyczyłyby niedalekiej przeszłości i wydawałyby się prawdopodobne, lecz obecnie nie ma bezpośredniego zagrożenia, przełożony rozstrzyga, czy zastosować wobec duchownego środki zapobiegawcze, czy odsunąć go od pracy z dziećmi i młodzieżą do czasu wyjaśnienia sprawy. Jeśli chodzi o oskarżenia o czyny sprzed wielu lat zasada ta powinna być stosowana z zachowaniem odpowiedniej słuszności. W przypadkach tych przełożony powinien zachęcić duchownego do wyrażenia uprzedniej, wyraźnej, świadomej i wolnej zgody na poddanie się specjalistycznej diagnozie, czy też, jeśli byłoby to konieczne, także terapii. Do czasu wyjaśnienia zarzutów duchowny nie może być dopuszczony do posługi ani nie może zostać przeniesiony do pracy w innej diecezji". 


\section{Zakończenie}

Przeanalizowane normy kodeksowe pozwalają wysnuć jeden wniosek: prawodawca kościelny troszczy się o to, by nie dopuścić do wystąpienia zgorszenia wiernych. Zakres podjętych w tym opracowaniu badań dotyczył właśnie sytuacji, w których może do tego dojść. By temu zapobiec, ustawodawca polecił konkretne działania, zawarte w ośmiu kanonach normujących różne sytuacje. I tak, duchowni winni wystrzegać się kontaktów z osobami, których postępowanie mogłoby narazić ich na problemy z zachowaniem celibatu. Przy sprawowaniu Eucharystii w świątyni niekatolickiej należy ściśle przestrzegać wydanych w tej materii norm kościelnych. W przypadku spowiedzi przy pomocy tłumacza należy zadbać, by nie ucierpiało na tym dobre imię penitenta. Obowiązek zachowania tajemnicy o tajnym zawarciu małżeństwa zostaje uchylony, gdy tego wymaga dobro sprawy. Spełnienie prawem wymaganych warunków pozwala udzielić pogrzebu jawnym grzesznikom. W pewnych sytuacjach w procesie karnym i spornym można zobowiązać do zachowania tajemnicy. Ordynariusz jest uprawniony, by nałożyć na oskarżonego konkretne ograniczenia w życiu i posłudze.

W tych właśnie sytuacjach należy nie dopuścić do zgorszenia. Przeprowadzona analiza pozwoliła ukazać sens istnienia tych prawnych procedur, mających na uwadze przede wszystkim dobro wiernych, a konkretnie ustrzeżenie ich przed zgorszeniem, które mogłoby mieć miejsce, gdyby nie wcześniejsza ingerencja kościelnego przełożonego.

\section{Ways of Preventing Depravity in the Light of the Code of Canon Law 1983}

The topic of depravity is present not only in moral theology, but it remains the subject of interest of the canon law. This phrase is present in numerous canons of the Code of Canon Law 1983 in the context of different legal situations. In this paper we turn attention to these situations which might result in depravity. Yet, depravity has not taken place, however the situation borders on it. Hence there are following situations analysed: these relations of clergy which may cause depravity, preventing depravity when Eucharist 
is celebrated in a non-Catholic temple; preventing depravity in case of confession with assistance of a translator, depravity vs. keeping secret of in case of marriage celebrated in secret, a danger of depravity in case of funeral of public sinners; keeping secret in the court trials, both criminal and contentious ones; prevention of depravity in hearing witnesses; preventive ordinations of the ordinary. In these situations the law maker advises to undertake proper actions to prevent depravity.

SŁOWA KLUCZOWE: zgorszenie; przestępstwo; prawo karne; sankcje karne

KEYWORDS: depravity; delict; criminal law; penal sanctions

\section{NOTA O AUTORZE}

O. DR hAB. MARek SAJ CSsR, PRof. UCZelni - pracownik naukowo-dydaktyczny na Wydziale Prawa Kanonicznego Uniwersytetu Kardynała Stefana Wyszyńskiego w Warszawie, kierownik Zakładu Kanonicznego Prawa Karnego. 